\title{
DNA Replication Licensing Factor MCM4
}

National Cancer Institute

\section{Source}

National Cancer Institute. DNA Replication Licensing Factor MCM4. NCI Thesaurus. Code C33909.

DNA replication licensing factor MCM4 (863 aa, 97 kDa) is encoded by the human MCM4 gene. This protein is involved in the initiation of DNA replication. 